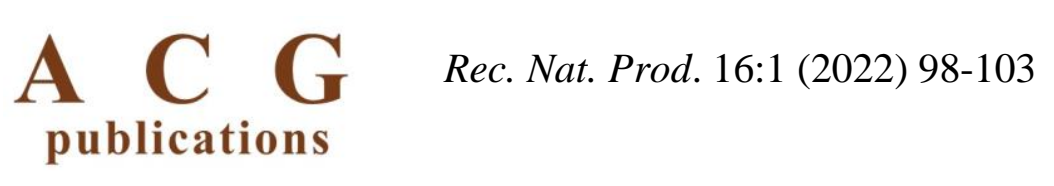

\title{
Two New Sesquiterpenoids from Chloranthus henryi Hemsl
}

\section{Yuting Bian $\mathcal{C}^{1^{*}}$, Fangyou Chen $\oplus^{1^{*}}$,Weiming Huang $\oplus^{1^{*}}$, Zhichao Chen ${ }^{1}{ }^{1 *}$, Pengcheng Shuang $\oplus^{2}$ and Yongming Luo $\oplus^{1 *}$}

\author{
${ }^{I}$ School of Pharmacy, Jiangxi University of Traditional Chinese Medicine, \\ Nanchang, Jiangxi 330004, P. R.China \\ ${ }^{2}$ School of Chinese Materia Medica, Beijing University of Chinese Medicine, \\ Beijing, 100029, P. R.China
}

(Received February 02, 2021; Revised April 18, 2021; Accepted April 19, 2021)

\begin{abstract}
Two new Chloratene F (1) and Chlomultin G (2), along with eight known sesquiterpenes (3-10) and six other known compounds (11-16) were isolated from the whole plant of Chloranthus henryi. Their structures were elucidated by HR-ESI-MS, NMR spectroscopic. The absolute configuration of two new compounds were determined by the X-ray crystallographic. All the compounds were reported for the first time from this species.
\end{abstract}

Keywords: Chloranthus henryi; Chloratene F; Chlomultin G; sesquiterpene; absolute configuration. (C) 2021ACG Publications. All rights reserved.

\section{Plant Source}

The whole plant of Chloranthus henryi were collected from the Jinggang Mountain, Jiangxi Province, China, on November 2018, and identified by A. Prof Kezhong Deng, Jiangxi University of Traditional Chinese Medicine, Nanchang, China. The voucher specimen (No.20181126) was deposited in the herbarium of the Faculty of Pharmacy, Jiangxi University of Traditional Chinese Medicine.

\section{Previous Studies}

The Chloranthus henryi Hemsl is a Chloranthus Swartz plant of Chloranthaceae, which is mostly distributed in southwest China [1-2]. Its whole grass, root and rhizome are a kind of traditional Chinese medicine commonly were used to treat injury, promot blood, remove blood stasis and rheumatoid arthritis [3-5]. In recent years, pharmacological studies on the Chloranthus henryi have shown that most of the plants have good antibacterial and anti-tumor activities [6-8]. Related studies also show that sesquiterpenes rich in Chloranthus henryi are the main active components of their antibacterial and anti-tumor activities $[9,10]$. Thus, it is necessary to study sesquiterpene compounds.

\footnotetext{
* Corresponding author: E- Mail:10ym999@126.com (Y. -M. Luo), Phone : +086-13970058758. $\underline{1964306673 @ q q . c o m}$ (Y.Bian) 


\section{Present Study}

In the process of phytochemistry research on characteristic medicinal plants in Jiangxi Province [1-3]. We research Chloranthus henryi Hemsl, it is a Chloranthus Swartz plant of Chloranthaceae, We report on the structure elucidation of sixteen compounds (1-16) were isolated from the whole of Chloranthus henryi for the first time, including two new sesquiterpenoids Chloratene F (1) and Chlomultin G (2) (Figure 1).

The dried powder of the whole plants $(23 \mathrm{~kg})$ of $C$. henryi was extracted with $95 \% \mathrm{EtOH}$ $(3 \times 100 \mathrm{~L})$ for 3 times, after combining the extract, the extract was decompressed and concentrated to no alcohol flavor, and the total extract was $1100 \mathrm{~g}$. The total extract was eluted with petroleum ether, $\mathrm{CH}_{2} \mathrm{Cl}_{2}$, EtOAc and $\mathrm{MeOH}$ in turn by diatomite column chromatography. After vacuum concentration, the eluents obtained $156.3 \mathrm{~g}$ of petroleum ether, $394.2 \mathrm{~g} \mathrm{Cf}_{2} \mathrm{Cl}_{2}, 94.6 \mathrm{~g}$ of EtOAc and $454.9 \mathrm{~g}$ of $\mathrm{MeOH}$. The $\mathrm{CH}_{2} \mathrm{Cl}_{2}$ extract (128 g) was chromatographed over an PRP 512A ( $\left.\mathrm{MeOH} / \mathrm{H}_{2} \mathrm{O}, 30 \%-95 \%\right)$ to yield four fractions (A-D). Fr.B (100g) was chromatographed over a silica gel CC eluted with petroleum ether-EtOAc in a gradient (30:1-0:1), to afford 5 fractions (B1-B5). Fr.B2 were purified by a silica gel column $\left(\mathrm{CH}_{2} \mathrm{Cl}_{2} / \mathrm{MeOH}, 50: 1-0: 1\right)$, and then a Sephadex LH-20 (MeOH) column to give 3 $(9.0 \mathrm{mg}), \mathbf{4}(5.6 \mathrm{mg}), \mathbf{5}(7.8 \mathrm{mg}), \mathbf{7}(10.2 \mathrm{mg})$ and $\mathbf{1 3}(5.3 \mathrm{mg})$. Fr. B3 (6.9 g) was separated by silicagel $\left(\mathrm{CH}_{2} \mathrm{Cl}_{2} / \mathrm{MeOH}, 50: 1-0: 1\right)$ as eluent, and then a ODS column chromatography eluted with $\mathrm{MeOH} / \mathrm{H}_{2} \mathrm{O}$ (50:50-80:20) to give three fractions (B3a-B3c). Fr.B3a was separated by preparative HPLC using $\mathrm{MeOH} / \mathrm{H}_{2} \mathrm{O}(65: 35)$ to give $\mathbf{1}(7.0 \mathrm{mg}), 2$ (6.6 mg), $6(8.8 \mathrm{mg}), \boldsymbol{8}(12.1 \mathrm{mg}), \boldsymbol{9}(11.0 \mathrm{mg})$ and 10 (7.4 mg). Fr.B3b (5.0 g) was separated by silica-gel (200-300 mesh) using $\mathrm{CH}_{2} \mathrm{Cl}_{2} / \mathrm{MeOH}$ (30:1-0:1), and by preparative HPLC $\left(\mathrm{C}_{2} \mathrm{H}_{3} \mathrm{~N} / \mathrm{H}_{2} \mathrm{O}, 55: 45\right)$ to obtain $11(7.8 \mathrm{mg}), 12(10.6 \mathrm{mg}), \mathbf{1 4}$ (9.4 mg), 15 (10.4 mg) and $\mathbf{1 6}(8.4 \mathrm{mg})$.
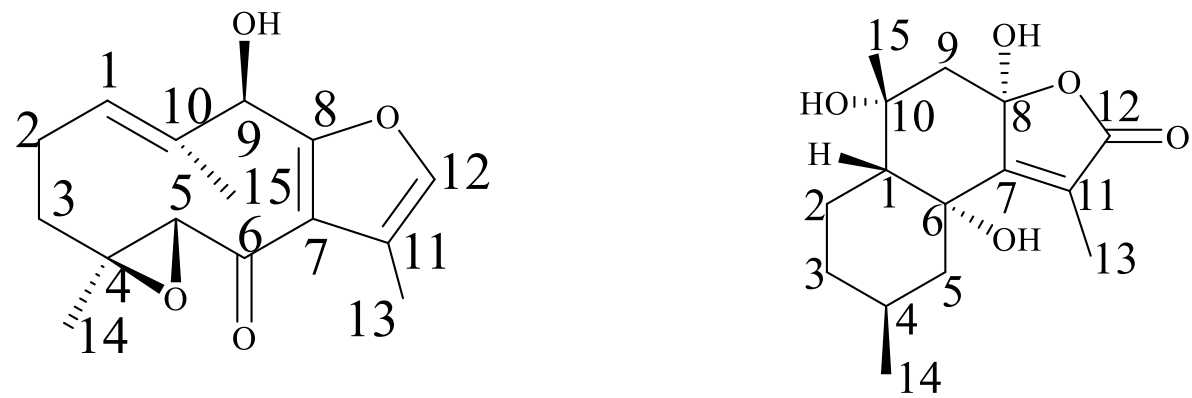

Figure 1. Structure of compounds 1 and $\mathbf{2}$ isolated from $C$. henryi

Chloratene $F(\mathbf{1})$ : Colorless granular crystal $(\mathrm{MeOH}) ;[\alpha]_{\mathrm{D}}{ }^{24}=-8.32(c=0.46, \mathrm{MeOH})$, HR-ESI-MS $m / z 285.1099[\mathrm{M}+\mathrm{Na}]^{+}$(calcd for $\mathrm{C}_{15} \mathrm{H}_{18} \mathrm{O}_{4} \mathrm{Na}, 285.1084$ ); X-ray crystallography data: $\mathrm{C}_{15} \mathrm{H}_{18} \mathrm{O}_{4}, M=$ $261.28 \mathrm{~g} / \mathrm{mol}$, orthorhombic, $\mathrm{P} 2_{1}, \mathrm{a}=7.9436(3) \AA, \mathrm{b}=12.2385(3) \AA, \mathrm{c}=13.8003(4) \AA, \mathrm{V}=$ 1341.63(7) $\AA 3, Z=4, T=293.0 \mathrm{~K}$, Dcalc $=1.294 \mathrm{~g} / \mathrm{cm}^{3}, 2351$ reflections independent, $R_{1}=0.0376$ and $\mathrm{wR}_{2}=0.0993$. Flack parameter $=0.04$ (14). (deposition number $:$ CCDC 2053107); ${ }^{1} \mathrm{H}$ NMR (600 $\left.\mathrm{MHz}, \mathrm{CDCl}_{3}\right)$ and ${ }^{13} \mathrm{C} \mathrm{NMR}\left(150 \mathrm{MHz}, \mathrm{CDCl}_{3}\right)$ data, see Table 1.

Chlomultin $G(2)$ : Colorless granular crystal $(\mathrm{MeOH}) ;[\alpha]_{\mathrm{D}}^{24}=-7.51(c=0.37, \mathrm{MeOH})$; HR-ESI-MS $m / z 281.1394$ [M-H] ${ }^{-}$(calcd for $\mathrm{C}_{15} \mathrm{H}_{21} \mathrm{O}_{5}, 281.1390$ ); X-ray crystallography data: for $\mathrm{C}_{15} \mathrm{H}_{22} \mathrm{O}_{5}, M=$ $279.30 \mathrm{~g} / \mathrm{mol}$, orthorhombic, $\mathrm{P} 2_{1}, \mathrm{a}=8.10670(10) \AA \mathrm{A}, \mathrm{b}=10.69920(10) \AA \mathrm{A}, \mathrm{c}=16.1887$ (2) $\AA$, $\mathrm{V}=$ 1404.13(3) $\mathrm{A}, \mathrm{Z}=4, \mathrm{~T}=293(2) \mathrm{K}$, Dcalc $=1.321 \mathrm{~g} / \mathrm{cm}^{3}, 2559$ reflections independent, $\mathrm{R}_{1}=0.0326$ and $\mathrm{wR}_{2}=0.0892$. Flack parameter $=0.10$ (8). (deposition number : CCDC 2059824); ${ }^{1} \mathrm{H}$ NMR (600 $\left.\mathrm{MHz}, \mathrm{CDCl}_{3}\right)$ and ${ }^{13} \mathrm{C} \mathrm{NMR}\left(150 \mathrm{MHz}, \mathrm{CDCl}_{3}\right)$ data, see Table 1. 
Table 1. The NMR datas for $\mathbf{1}$ and $\mathbf{2}$ in $\mathrm{CDCl}_{3}(\delta$ in ppm, $J$ in $\mathrm{Hz}$ )

\begin{tabular}{|c|c|c|c|c|}
\hline \multirow[t]{2}{*}{ NO. } & \multicolumn{2}{|l|}{1} & \multicolumn{2}{|l|}{2} \\
\hline & $\delta_{\mathrm{H}}$, mult. $(J$ in $\mathrm{Hz})$ & $\delta \mathrm{C}$ & $\delta_{\mathrm{H}}$, mult. $(J$ in $\mathrm{Hz})$ & $\delta \mathrm{c}$ \\
\hline 1 & $6.04(1 \mathrm{H}, \mathrm{m})$ & 126.2 & $1.38(1 \mathrm{H}, \mathrm{dd}, J=12.3,3.7 \mathrm{~Hz})$ & 52.5 \\
\hline $2 \mathrm{a}$ & $2.59(1 \mathrm{H}, \mathrm{m})$ & & $1.77(1 \mathrm{H}, \mathrm{m})$ & 22.1 \\
\hline $2 \mathrm{~b}$ & $2.30(1 \mathrm{H}, \mathrm{m})$ & 25.9 & $1.90(1 \mathrm{H}, \mathrm{m})$ & \\
\hline $3 \mathrm{a}$ & $2.32(1 \mathrm{H}, \mathrm{m})$ & 38.1 & $1.01(1 \mathrm{H}, \mathrm{m})$ & 35.4 \\
\hline $3 b$ & $1.33(1 \mathrm{H}, \mathrm{m})$ & & $1.79(1 \mathrm{H}, \mathrm{m})$ & \\
\hline 4 & - & 64.2 & $1.96(1 \mathrm{H}, \mathrm{m})$ & 28.0 \\
\hline $5 \mathrm{a}$ & $3.93(1 \mathrm{H}, \mathrm{d}, J=1.0 \mathrm{~Hz})$ & 66.4 & $2.18(1 \mathrm{H}, \mathrm{m})$ & 46.5 \\
\hline $5 b$ & & & $1.50(1 \mathrm{H}, \mathrm{m})$ & \\
\hline 6 & - & 192.6 & - & 75.0 \\
\hline 7 & - & 123.7 & - & 160.5 \\
\hline 8 & - & 157.0 & - & 105.8 \\
\hline $9 \mathrm{a}$ & $5.30(1 \mathrm{H}, \mathrm{s})$ & 71.2 & $1.77(1 \mathrm{H}, \mathrm{m})$ & 51.3 \\
\hline $9 b$ & & & $2.49(1 \mathrm{H}, \mathrm{m})$ & \\
\hline 10 & - & 131.9 & - & 73.0 \\
\hline 11 & - & 121.9 & - & 122.5 \\
\hline 12 & $7.19(1 \mathrm{H}, \mathrm{t}, J=1.2 \mathrm{~Hz})$ & 139.4 & - & 174.5 \\
\hline 13 & $2.12(1 \mathrm{H}, \mathrm{d}, J=1.3 \mathrm{~Hz})$ & 10.3 & $2.05(3 \mathrm{H}, \mathrm{s})$ & 10.3 \\
\hline 14 & $1.55(3 \mathrm{H}, \mathrm{s})$ & 15.3 & $0.96(3 \mathrm{H}, \mathrm{d}, J=6.7 \mathrm{~Hz})$ & 22.6 \\
\hline 15 & $1.35(3 \mathrm{H}, \mathrm{s})$ & 15.2 & $1.98(3 \mathrm{H}, \mathrm{s})$ & 28.4 \\
\hline
\end{tabular}

Compound 1 was isolated as colorless granular crystal, The molecular formula was determined as $\mathrm{C}_{15} \mathrm{H}_{18} \mathrm{O}_{4}$ by the HR-ESI-MS $\left(\mathrm{m} / z 285.1099[\mathrm{M}+\mathrm{Na}]^{+}\right.$, calcd. 285.1084) with seven degrees of unsaturation. The ${ }^{1} \mathrm{H}-\mathrm{NMR}$ spectrum showed three methyl groups at $\delta_{\mathrm{H}} 2.12(3 \mathrm{H}, \mathrm{d}, J=1.3 \mathrm{~Hz}, \mathrm{H}-13)$, $1.55(3 \mathrm{H}, \mathrm{s}, \mathrm{H}-14)$ and $1.35(3 \mathrm{H}, \mathrm{s}, \mathrm{H}-15)$, two olefinicprotons at $\delta_{\mathrm{H}} 6.04(1 \mathrm{H}, \mathrm{m}, \mathrm{H}-1)$ and $7.19(1 \mathrm{H}, \mathrm{t}$, $J=1.2 \mathrm{~Hz}, \mathrm{H}-12)$, two methylene at $\delta_{\mathrm{H}} 2.59(1 \mathrm{H}, \mathrm{m}, \mathrm{H}-2 \mathrm{a}), 2.30(1 \mathrm{H}, \mathrm{m}, \mathrm{H}-2 \mathrm{~b})$ and $2.32(1 \mathrm{H}, \mathrm{m}, \mathrm{H}-$ $3 \mathrm{a}), 1.33(1 \mathrm{H}, \mathrm{m}, \mathrm{H}-3 \mathrm{~b})$. The combination of ${ }^{13} \mathrm{C}-\mathrm{NMR}$ and $\mathrm{HSQC}$ data indicated 15 carbon resonances, including three methyl $\delta_{C} 10.3(\mathrm{C}-13), 15.3(\mathrm{C}-14)$, and $15.2(\mathrm{C}-15)$, two methylene $\delta_{\mathrm{C}}$ $23.9(\mathrm{C}-2), 38.1(\mathrm{C}-3)$, one oxygen-substituted $\delta_{C} 71.2(\mathrm{C}-9)$, two dioxycarbons $\delta_{\mathrm{C}} 64.2(\mathrm{C}-4), 66.4(\mathrm{C}-$ 5). This deduction was supported by the HMBC correlations from Me-13 to $\mathrm{C}-11$ and 12 , and from $\mathrm{H}-$ 12 to $\mathrm{C}-7,8,11$ and 13 indicated 1 contains one methyl located in C-11. Respectively, other correlations from Me-15 to C-3, 4 and 5, Me-14 to C-1, 10 and $9, \mathrm{H}-9$ to C-1 , 7 and 10, H-1 to C-2, 9, 15 and 10, H-5 to C-4 and 6 observed in HMBC, together with the six indices of hydrogen deficiency, structurally similar with zederone [11], however, the chemical shift of $\delta_{\mathrm{C}} 71.2$ for C-9 in $\mathbf{1}$ was different from its shift of $\delta_{\mathrm{C}} 71.2$ in zederone. Analysis of the indices of hydrogen deficiency and the chemical shifts indicated that C-9 carried a hydroxy substituent in $\mathbf{1}$. The planar structure of $\mathbf{1}$ was thus identified as a germacrane sesquiterpenoid. Meanwhile, according to the X-ray crystallography (Figure 3 ) of the compound $\mathbf{1}$. Thus, the absolute configuration of the compound is determined as $(4 S$, $5 R, 9 R)$.

Compound 2 was isolated as colorless granular crystal. The molecular formula was determined as $\mathrm{C}_{15} \mathrm{H}_{22} \mathrm{O}_{5}$ by the HR-ESI-MS $\left(\mathrm{m} / z 2281.1394[\mathrm{M}-\mathrm{H}]^{-}\right.$, calcd. 281.1390) with five degrees of unsaturation. The ${ }^{1} \mathrm{H}-\mathrm{NMR}$ spectrum exhibited three methyl groups $\delta_{\mathrm{H}} 2.05(3 \mathrm{H}, \mathrm{s}, \mathrm{H}-13), 0.96(3 \mathrm{H}, \mathrm{d}$, $J=6.7 \mathrm{~Hz}, \mathrm{H}-14)$ and $1.98(3 \mathrm{H}, \mathrm{s}, \mathrm{H}-15)$, two methine $\delta_{\mathrm{H}} 1.38(1 \mathrm{H}, \mathrm{dd}, J=12.3,3.7 \mathrm{~Hz}, \mathrm{H}-1)$ and 1.96 $(1 \mathrm{H}, \mathrm{m}, \mathrm{H}-4)$. The ${ }^{13} \mathrm{C}$ NMR spectrum of 2 showed signals of three methyl, four methylene, two methine, and six quaternary carbons include three $-\mathrm{OH}$ signals at $\delta_{\mathrm{C}}(75.0,105.8,73.0)$. In HMBC spectrum, cross-peaks from H-5 to C-3, 4 and 6, from H-9 to C-7, 8 and 10, Me-14 to C-3, 4 and 5, and from Me-15 to C-9 and 10, and Me-13 to C-11 and 12. The three - $\mathrm{OH}$ groups were connected to C-6, C-8, and C-10 by the HMBC cross-peaks from H-9 to C-8 and 10, and from H-1 and H-5 to C-6. Meanwhile, the absolute configuration of the compound 2 was determined to be $(1 S, 4 S, 6 R, 8 R, 10 R)$ by the X-ray crystallography (Figure 3 ). 


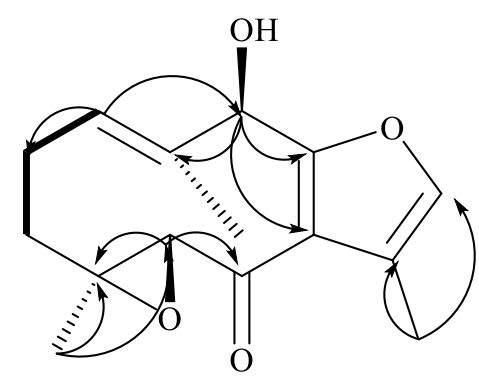

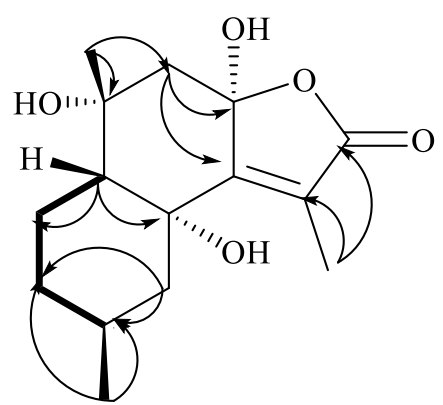

$\mathrm{H}^{1}-\mathrm{H}^{1} \mathrm{COSY}:-\operatorname{HMBC}(\mathrm{H} \rightarrow \mathrm{C}): \frown$

Figure 2. Key $\mathrm{H}^{1}-\mathrm{H}^{1} \mathrm{COSY}$ and $\mathrm{HMBC}$ correlations of compounds $\mathbf{1}$ and $\mathbf{2}$ Q2

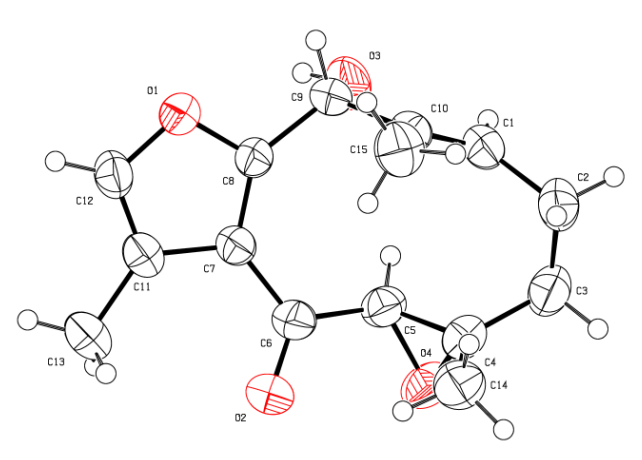

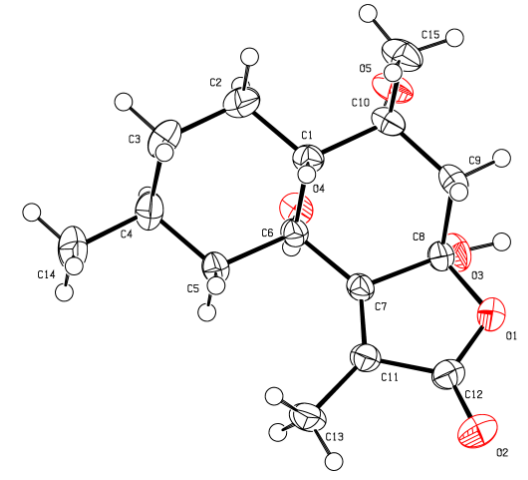

Figure 3. ORTEP drawing of compounds $\mathbf{1}$ and $\mathbf{2}$

The fourteen known sesquiterpenes were identified as chlorajapolide I (3) [12], chloraniolide A (4) [13], 8 $\beta$-Hydroxy-isogermafurenolide (5) [14], neolitacumone C (6) [15], 4(R),15-epoxyatractylenolide II (7) [16], japonicone A (8) [17], spicachlorantin C (9) [18], shizukaol F (10) [19], 7'hydroxyisoasperphenamate (11) [20], 2 $\alpha, 3 \beta$-dihydroxy-urs-12-en- 28-oic acid (12) [21], euscaphic acid (13) [22], hemisesmin-1 (14) [23], mycophenolic methyl ester (15) [24], 4-hydroxy-2,3-dimethyl2-nonen-4-olide (16) [25] by comparing their NMR and MS date with those reported in the literature. All of them were found in this plant for the first time.

\section{Acknowledgments} (82060697).

This work was partially supported by the National Natural Science Fundation of china

\section{Supporting Information}

Supporting Information accompanies this paper on http://www.acgpubs.org/journal/records -of-natural-products

\section{ORCID}

Yuting Bian:0000-0002-8500-0418

Fangyou Chen:0000-0002-4650-3987

Weiming Huang:0000-0003-2707-7246

Zhichao Chen:0000-0002-4779-6240

Pengcheng Shuang:0000-0002-4612-9913

Yongming Luo:0000-0001-9688-9956 
Sesquiterpenoids from Chloranthus henryi

\section{References}

[1] Editorial Committee of China. Flora of the Chinese Academy of Science (1982). Beijing: Science Press. 20, 79-80.

[2] X. W. Yang (2017). Bioactive material basis of medicinal plants in Genus Chloranthus, Mod. Chin. Med. 4, 459 - 495 .

[3] G. Luo, H. X. Ma, Y. M. Luo and X. Y. Yi (2014). Simultaneous determination of coumarin and sesquiterpene lactone content of active ingredients in chloranthus species by HPLC, Chin. J. Exp. Tradit. Med. Form. 20, 47 - 50.

[4] F. Y. Chen, H. T. Li, C. J. Li, J. Chen, J. W. Huang, C. Li and Y. M. Luo (2020). Neuroprotective racemic germacranolides from the roots of Chloranthus henryi, Fitoterapia 141, 104472

[5] H. Yan, X. J. Qin, X. H. Li, Q. Yu, W. Ni, L. He and H. Y. Liu (2019). Japonicones A-C: three lindenane sesquiterpenoid dimers with a 12-membered ring core from Chloranthus japonicus, Tetrahedron Lett. 60, $713-717$.

[6] L. L. Pan, P. Xu, X. L. Luo, L. J. Wang, S. Y. Liu, Y. Z. Zhu, J. F. Hu and X. H. Liu (2017). Shizukaol B, an active sesquiterpene from Chloranthus henryi, attenuates LPS-induced inflammatory responses in BV2 microglial cells, Biomed. Pharmacother. 88, 878 - 884.

[7] M. L. Zhang, D. Liu, G. Q. Fan, R. X. Wang, X. H. Lu, Y. C. Gu and Q. W. Shi (2016). Constituents from Chloranthaceae plants and their biological activities, Heterocycl. Commun. 22, 175 - 220.

[8] Y. M. Luo, Y. D. Luo, F. Y. Chen, H. Liu and J. J. Fu (2014). Studies on the chemical constituents of Chloranthus henryi, Adv. Mater. Res. 1033, 279 - 282.

[9] H. Z. Fu, Y. M. Luo, H. Liu, D. M. Zhang and T. F. Ji (2010). A new tetrahydrophenanthrene from Chloranthus henry, Chinese Chem. Lett. 21, 206-208.

[10] B. Wu, S. He and Y. J. Pan (2007). Sesquiterpenoid with new skeleton from Chloranthus henryi, Tetrahedron Lett. 48, 453-456.

[11] L. J. Wang, J. Xiong, S. T. Liu, X. H. Liu and J. F. Hu (2014). Sesquiterpenoids from Chloranthus henryi and their anti-neuroinflammatory activities, Chem. Biodivers. 11, 919 - 928.

[12] M. Zhang, J. S. Wang, P. R. Wang, M. Oyama, J. Luo, T. Ito, M. Iinuma and L. Y. Kong (2012). Sesquiterpenes from the aerial part of Chloranthus japonicus and their cytotoxicities, Fitoterapia 83, 1604-1609.

[13] Y. J. Xu, C. P. Tang, M. J. Tan, C. Q. Ke, T. Wu and Y. Ye (2010). Sesquiterpenoids and diterpenoids from Chloranthus anhuiensis, Chem. Biodivers. 7, 151-157.

[14] C. M. Zhang, J. B. Ji, M. Ji and P. H. Fan (2015). Acetylcholinesterase inhibitors and compounds promoting SIRT1 expression from Curcuma xanthorrhiza, Phytochem Lett. 12, 215-219.

[15] F. R. Chang, T. J. Hsieh, T. L. Huang, C. Y. Chen, R. Y. Kuo, Y. C. Chang, H. F. Chi and Y. C. Wu (2002). Cytotoxic constituents of the stem bark of Neolitsea acuminatissima, J. Nat. Prod. 65, 255-258.

[16] Y. Li, J. Liu and X. W. Yang (2013). Four new eudesmane-type sesquiterpenoid lactones from atractylenolide II by biotransformation of rat hepatic microsomes, J. Asian. Nat.Prod. Res. 15, 344-356.

[17] H. Yan, X. J. Qin, X. H. Li, Q. Yu, W. Ni, L. He and H. Y. Liu (2019). Japonicones A-C: three lindenane sesquiterpenoid dimers with a 12-membered ring core from Chloranthus japonicus, Tetrahedron Lett. 60, 713-717.

[18] S. Y. Kim, Y. Kashiwada, K. Kawazoe, K. Murakami, H. D. Sun, S. L. Li and Y. Takaishi (2009). Spicachlorantins C-F, hydroperoxy dimeric sesquiterpenes from the roots of Chloranthus spicatus, Tetrahedron Lett. 50, 6032-6035.

[19] J. Kawabata, E. Fukushi and J. Mizutani (1995). Sesquiterpene dimers from Chloranthus japonicus, Phytochemistry. 39, 121-125.

[20] A. Syuhei, W. Daigo, I. Takeshi, T. Hisashi, Y. Takashi, T. G. M. Campos and H. Tomoo (2017). New two pebrolide derivatives, 14-deacetoxy-1-deoxypebrolide and 7'-hydroxyasperphenamate isolated from Penicillium sp. IFM62525, Heterocycles : an international journal for reviews and communications in heterocyclic chemistry, 94, 326-333.

[21] Y. Min, L. Zhang, J. M. Guo, K. Gu and M. H. Qiu (2006), Study on chemical constituents of Punica Granatum, J. Anhui Agri. Sci. 34, 2635-2637.

[22] P. N. Wu, H. Q. Duan, Z. Yao, Q. Pan and F. G. Zhang (2007). Triterpenoids with anticancer activity in Duchesnea in dica Focke, Chin. Tradit. Herbal Drugs. 38, 1311-1313.

[23] L. P. Zhu, Y. Li, J. Z. Yang, L. Zuo and D. M. Zhang (2008). Studies on chemical constituents of Sarcandra glabra, China J. Chin. Mater. Med. 33, 155-157. 
[24] J. Rovirosa, A. Diaz-Marrero, J. Darias, K. Painemal and A. S. Martin (2006). Secondary metabolites from marine penicillium brevicompactum, J. Chil. Chem. Soc. 51, 775-778.

[25] C. Li, I. Shunsuke, I. I. Diana, I. Tomoko, U. Ryoichi and H. Toshifumi (1996). Secretion of allelochemicals from the cultured Suspension cells of Marchantia polymorpha, Chem. Lett. 25, 205-206.

\section{A C G \\ publications \\ (C) 2021 ACG Publications}

